\section{THE ANATOMY AC'T.}

THE following is the petition drawn up by $\mathrm{Mr}$. Morrison, for which we were unable to find room in our report of the meeting of the North of England Association.

To the Honourable the Commons in Parliament assembled.

'T'he humble Petition of the President and Members of the North of England Medical Association, assembled in the city of Durham.

Sheweth,-That your petitioners are impressively convinced, that without a well-grounded and minute knowledge of the structure and functions of the human frame-a knowledge only to be acquired by frequent and careful dissections of the human body-the physician and surgeon are incompetent, with benefit to the public, to practise their respective professions; that, wanting such knowledge, their art is a fearful instrument of danger in their hands; and that, moreover, the advancement of the science of medicine is in a great measure, if not wholly, dependent on the discoveries made through human and comparative anatomy.

'That your petitioners, therefore, deeply deplore the limited means of acquiring the amount of anatomical knowledge indicated, afforded them by the $2 \mathrm{~d}$ and $3 \mathrm{~d}$ Wm. IV., cap. 75, commonly called the Anatomy Act, and humbly approach your honourable house with a prayer for such amendments in it as will remove the grievances complained of.

That English students in medicine, aware of the many difficulties which, under the operation of the Anatomy Act, beset their path, are compelled to abandon the superior instructions and practice of their native teachers, and to resort to such continental schools as are provided, by the law of the land, with sufficient means for prosecuting this most important branch of medical science.

'That your petitioners humbly refer your honourable house to the 7 th clause of the act in question, which provides, "that any person having lawful possession of a deceased body may deliver up the same for dissection, unless the deceased person, previously to his death, shall have otherwise by will disposed of his body, or unless the said body is subsequently claimed by a known relation."

'Ihat in reference to the above clause, your petitioners humbly beg to point out to your honourably house that cases frequently arise when it is difficult or impossible to define who is the lawful possessor of the body, and that not only does inconvenience and danger of violating the statute result to the licensed teacher of anatomy from such ambiguity of expression, but the ambiguity is taken advantage of by persons prejudiced against dissection, to elude the intention of the statute. That instead of a discretionary power being given to persons (not relatives) having lawful possession of dead bodies, your petitioners humbly suggest that the requirements of the anatomical students make it imperatively desirable that it should be compulsory on such persons having lawful possession of a body, to deliver up the same when demanded by a licensed teacher of anatomy.

That your petitioners urge the above alterations-

1st. Because it would amply provicle for the requirements of the anatomical student. 2nd. Because the compulsory enactment, while it would materially advantage the living, would in no wise prejudice the dead; and that, inasmuch as no relatives would survive a body so disposed of, no objection could be urged against the change on the score of violation of feelings.

3rd. Because it would remove from the shoulders of public functionaries, who, for the most part, hold possession of unclaimed bodies, the responsibility of a discretion which they universally fear to exercise.

That to facilitate the operation of the act under the proposed change, your petitioners humbly point out that a clause should be inserted to provide for the immediate removal of unclaimed bodies to a public dead-house, whence they may be removed, whether to the burial-ground or dissection room, without public observation.

That your petitioners regret the general ambiguity in the construction of the Act, and humbly pray that your honourable house will remove from it all contradictory instructions, and render its provisions lucid and intelligible.

'That your honourable house will delegate to the several registrars of births, deaths, and marriages, residing in districts where anatomical schools exist, or the inspector of anatomy, where such officer has been appointed, authority and power to give timely notice to the teacher of anatomy, licensed under the seal of her Majesty's chief secretary of state for the home department, of the death of any unclaimed person, and to remove the body of the same to such central deadhouse as shall be appointed, for the disposal or otherwise of the aforesaid teacher of anatomy.

That your petitioners, although practitioners in medicine, are perfectly sensible of the fact, that between the public and themselves there is an identity of interest; that no possible good can be sought by them, which can possibly operate to the disadvantage of the public; and that, in seeking the measure of reform detailed in the petition, they have no selfish, no mercenary object in view.

And your petitioners will ever pray, \&c.

\section{ASSOCIATION OF MEDICAL OFFICERS}

\section{ATTACHED TO}

\section{HOSPITALS FOR THE INSANE.}

$\Lambda$ T a meeting of medical gentlemen attached to lunatic asylums, held at the Gloucester Lunatic Asylum-Present: Dr. Shute, of the Gloucester Lunatic Asylum, in the chair; Mr. Powell, Nottingham; Mr. Wintle, Oxford; Mr. Thurnam, 'The Retreat, York; Mr. Gaskell, Lancaster Asylum; Dr. Hitch, Gloucester :

The following resolutions were adopted :-

That an Association be formed of the medical officers attached to hospitals for the insane, whose objects shall be-Improvement in the management of such institutions and the treatment of the insane, and the acquirement of a more extensive and more correct knowledge of insanity. That the medical gentlemen attached to hospitals for the insane be individually addressed, and requested to join the association.

That, by the members of this association, the 
terms lunatic, and lunatic asylum, be abandoned, except for legal purposes, and that the terms insane person, and hospital for the insane, be substituted.

'That to effect the great objects of this association, visits be made annually to some one or more of the hospitals for the insane in the United Kingdom; and that the order of rotation in which such visits shall be made, be determined at the several meetings.

'That the concurrence of the governors of the several hospitals to this arrangement be solicited by the respective medical officers.

That at its meetings the association ascertain and record, as far as possible, the medical and moral treatment adopted in each hospital.

'That to insure a careful comparison of the results of treatment in each, it is strongly recommended that uniform registers be kept, and that tabular statements, upon a like uniform plan, be circulated with the annual report of each hospital; or, where this is not practicable, that it be otherwise transmitted to the association.

'That, at the meetings, papers and essays be read; subjects of interest to the insane and to the association be discussed, and information communicated; and that a copy or minutes of these be preserved on the journal of the association.

(Signed)

Hardwicke Shute, Chairman.

July 27, 1841.

Forty-four medical officers of hospitals for the insane have already joined this association.

\section{BIRMINGHAM ROYAL SCHOOL OF ME- DICINE AND SURGERY.}

On Saturday last, a numerous and highly-respectable meeting of the council, patrons, and friends of the Birmingham Royal School of Medicine and Surgery, took place in the theatre of the institution, in Paradise-street, on the occasion of the annual distribution of prizes to those students who had distinguished themselves in the several departments of medical and surgical knowledge, as well as by their exemplary conduct and diligence during the past year.

Dr. Johnstone, the venerable and esteemed president of the institution, occupied the chair, and amongst the visitors who honoured the meeting with their presence, were the Right Rev. the Lord Bishop of Worcester, C. H. Bracebridge, Esq., Joseph Webster, Esq., J. E. Piercy, Esq., W. Room, Esq., (the low bailiff,) J. W. Whateley, Esq., Henry Van Wart, Esq., 'Thomas Clark, Esq., H. Burgess, Esq., (commissioner of police, the Members of the Council of the School and Queen's Hospital, Dr. Eccles, Dr. Percy, Dr. Birt Davies, Dr. Lloyd, Dr. Melson, Dr. Ingleby, Dr. Annesley, G. B. Knowles, Esq., W. Sands Cox, Esq., and other medical gentlemen. Amongst the clergy and ministers we observed, the Rev. J. Garbett, (rural dean,) the Rev. R. Kennedy, the Rev. J. P. Lee, the Rev. Sydney Gedge, the Rev. J. Gwyther, the Rev. J. W. Downes, the Rev. S. F. Morgan, the Rev. Colin Campbell, the Rev. M. W. Foye, the Rev. B. Spurrell, the Rev. I. Spooner, the Rev. J. Clarke, the Rev. J. Webster, the Revds, Messrs.
Crowther, Rowe, \&c., and the Rev. J. A. James. Letters were received from the Earl of Dartmouth, the Earl of Bradford, the Earl Howe, Iord Lyttelton, Viscount Lifford, Sir Robert Peel, the county and borough members, the Rev. Vaughan 'Thomas, and the Mayor, apologising for their unavoidable absence.

'The President opened the proceedings of the day by observing that they had assembled on one of the most interesting occasions that could occur - that of rewarding merit ; and the only difficulty which the council experienced was in discriminating between the excellence of the competitors, inasmuch as the whole of the pupils had distinguished themselves no less by their proficiency in their scientific pursuits than by their admirable conduct. The president then adverted to the munificent gifts of Dr. Warneford, who, in founding his prizes, was influenced by an anxious wish to combine with the acquisition and diffusion of medical instruction the great and important doctrines of Christianity; and concluded by calling upon Mr. Clay, to read the prize essay written by his brother, Mr. W.F.F. Clay of Handsworth, (who is now completing his studies at Cambridge,) " (On the Valvular Structure of the Human Heart, as an instance of example of the wisdom, power, and goodness of God, as revealed and declared in IIoly Writ."

Mr. Clay then proceeded to read the essay in question, which was listencel to with marked attention and interest $b y$ the audience, and clicited a general expression of applanse at its close.

The Lord Bishop of Worcester, in presenting the medal to Mr. Clay, pronounced an interesting discourse, in which his lordship clearly showed that the study of the human body, so far from leading to materialism and irreligion, tended to impress on the mind the existence of a great and supreme Cause.

Appropriate speeches were made by several other gentlemen, on handing over their honours to the different successful candidates.

The following is a list of the prizes presented on this interesting occasion :-

The first Warneford Gold Medal and Ten Pounds.-Presented ly the Lord Bishop of Worcester, to Mr. W. F. F. Clay, Handsworth.

The Jephson Prize, 'I'wenty Guineas, (offered by' Dr. Jephson of Leamington.)-Presented by the Rev. James Prince Lee, to Mr. John Davies of Stourbridge.

The Gold Medals for Regularity and Good Conduct, (offered by the Governors and Subscribers to the School.)-Presented by C. Holte Bracebridge, Esq., to Mr. Hind and Mr. James, both of this town.

First Medal, Anatomy, (offered by WT. S. Cox, Esq., and Langston Parker, Esq.)-Presented by the Rev. J. Clarke, Rector of Northfield, to Mr. James, of this town.

First Medal, Chemistry, (offered by J. Woolrich, Esq.) - Presented by J. E. Piercy, Esq., to Mr. G. H. Stallard of Leicester.

Second Medal, (offered by J. Woolrich, Esq.)Presented by J. E. Piercy, Esq., to Mr. G. Yates, of Dumbleton, Gloucestershire.

First Medal, Botany, (offered by G. B. Knowles, Esq.)-Presented by the Rev. R. Kennedy, to $\mathrm{Mr}$. J. C. Clarkson, of this town.

First Medal, Materia Medica, (offered by Dr. James Johnstone and G. B. Knowles, Esq.)- 